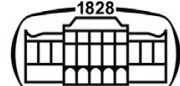

AKADÉMIAI KIADÓ

Acta Veterinaria

Hungarica

$68(2020) 1,105-111$

DOI:

$10.1556 / 004.2020 .00002$

(c) 2020 The Author(s)

\section{ORIGINAL ARTICLE}

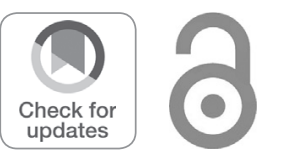

\title{
Low incidence of Schmallenberg virus infection in natural cases of abortion in domestic ruminants in Hungary
}

\section{LEVENTE SZEREDI $^{1 *} \oplus$, ÁDÁM DÁN ${ }^{1,2}$, PÉTER MALIK ${ }^{1}$, SZILÁRD JÁNOSI ${ }^{1}$ and ÁKOS HORNYÁK ${ }^{1}$}

\author{
${ }^{1}$ Veterinary Diagnostic Directorate, National Food Chain Safety Office, Tábornok utca 2, H-1143, \\ Budapest, Hungary \\ ${ }^{2}$ Present adress: SCG Diagnostics Ltd., Délegyháza, Hungary
}

Received: June 12, 2019 • Accepted: November 19, 2019

Published online: May 8, 2020

\begin{abstract}
An epizootic caused by a new orthobunyavirus called Schmallenberg virus (SBV) was recognised in European ruminants in 2011 and 2012. The re-emergence of the infection was reported in several countries in the subsequent years. Although the main clinical sign of SBV infection is abortion, the impact of SBV in natural cases of abortion in domestic ruminants had not been systematically examined before this study. The aim of the study was to investigate the role of SBV infection and to compare it to the importance of other causes of abortion by examining 537 natural cases of abortion that had occurred between 2011 and 2017 in Hungary. The cause of abortion was determined in 165 (31\%) cases. An infectious cause was proved in $88(16 \%)$ cases. SBV infection was found only in a total of four cases $(0.8 \%)$ using real-time polymerase chain reaction. Three of them proved to be inapparent SBV infection, and one case was attributed to SBV-induced abortion by detecting non-purulent encephalitis and SBV nucleoprotein by immunohistochemistry in a brain tissue sample. According to the results, SBV played a minor role in natural cases of domestic ruminant abortion in Hungary during the 7-year period following the first SBV outbreak in 2011.
\end{abstract}

\section{KEYWORDS}

Schmallenberg virus, abortion, frequency, domestic ruminants

\section{INTRODUCTION}

A new disease in dairy cattle was reported in north-western Germany and the Netherlands in the late summer and autumn of 2011. Sudden decrease in milk production, fever and diarrhoea, followed by abortion, premature birth or stillbirth were the main clinical signs (Wernike et al., 2015). The aborted fetuses presented severe congenital malformations, cavitations in the central nervous system, and myeloencephalitis (Herder et al., 2013). A new orthobunyavirus called Schmallenberg virus (SBV) was identified as the cause of the disease using next-generation sequencing-based metagenomic analysis (Hoffmann et al., 2012). SBV predominantly infects domestic and wild ruminants, but antibodies were also detected in dogs and wild boars (Wernike et al., 2015). The infection is transmitted by Culicoides as in the case of bluetongue virus (BTV), and it has spread quickly in Europe and the neighbouring areas (Wernike et al., 2015). SBV infection was detected in Hungary for the first time in October 2012 (Fehér et al., 2017).

There are reports dealing with the significance and economic aspects of SBV infection in domestic ruminants (Veldhuis et al., 2013; Dominguez et al., 2014). However, the relevance of SBV infection has not been determined so far in natural cases of abortion in the years following the emergence of SBV. The aim of the present retrospective study was to collect data about the prevalence of SBV-induced abortion between 2011 and 2017, and the 
importance of this infection compared to other causes of abortion in cattle, sheep and goats in Hungary.

\section{MATERIALS AND METHODS}

Samples were submitted in a total of 2,904 abortion cases from cattle, sheep and goats to the National Food Chain Safety Office Veterinary Diagnostic Directorate, Budapest from 15 out of the 19 counties of Hungary between 1 June 2011 and 31 December 2017. The majority of samples (from 2,367 cases) were intended for testing for bluetongue disease and/or brucellosis. Since no further investigations were applied in these cases, they were not included in the study. In the remaining 537 cases a detailed laboratory examination was performed, and these cases were selected for this study. Aborted fetuses from cattle (387 cases, 72\%), sheep (112 cases, $21 \%$ ) and goats (38 cases, $7 \%$ ) were subjected to gross pathological and histopathological examination. Fetal membranes were examined in 83 (21\%), $56(50 \%)$ and $12(36 \%)$ cases, respectively. For histopathological examination, brain, liver, spleen, kidney and fetal membranes were fixed in $8 \%$ buffered formalin, embedded in paraffin wax, cut into $4-\mu \mathrm{m}$ sections and stained with haematoxylin and eosin. Special histological stains (Brown-Brenn, Giemsa, periodic acidSchiff and Gömöri methenamine silver stains) and anti-BCG antibody-based immunohistochemistry (IHC, Table 1) were used to detect bacteria and fungi in suspected cases. Von
Kossa and Prussian blue stains were used for the detection of dystrophic calcification and previous haemorrhages, respectively, in brain tissue in cases of SBV infection and in cases presenting congenital malformations. Detection of Leptospira was attempted with Warthin-Starry staining in all cases. Leptospira-positive cases were confirmed by IHC (Table 1). IHC tests were used as well to detect Listeria monocytogenes and Salmonella spp. in fetal tissue samples and placenta to confirm the bacterial culture results (Table 1). Additionally, IHC was used for the detection of Chlamydiaceae, Coxiella burnetii, bovine herpesvirus-1 (BoHV-1) and Neospora caninum/Sarcocystis in cases with histopathological alterations suspicious for the corresponding infection (Table 1). In the case of a positive $N$. caninum/Sarcocystis result, Toxoplasma gondii IHC was applied on serial tissue sections to determine the presence or absence of T. gondii (Table 1). The occurrence of bovine virus diarrhoea virus (BVDV) was examined by IHC method (Table 1) on fetal calf brain tissue. Real-time polymerase chain reaction (RT-PCR) was used for the detection of BTV and SBV in fetal spleen and brain, respectively (Hofmann et al., 2008; Bilk et al., 2012; Fehér et al., 2017). SBV-positive cases and cases presenting congenital malformations were further examined by IHC to detect SBV nucleocapsid protein (Table 1). Bacterial culture was made in all cases from fetal stomach content and fetal membranes, if available, for the detection of Brucella, Campylobacter and aerobic bacteria.

All cases were analysed and classified into two main categories: known or unknown cause of abortion (Table 2).

Table 1. Dilution and source of the primary antibodies and the detection systems used in the immunohistochemical examination

\begin{tabular}{|c|c|c|c|c|}
\hline $\begin{array}{l}\text { Detected } \\
\text { pathogen }\end{array}$ & $\begin{array}{l}\text { Dilution of primary } \\
\text { antibody }\end{array}$ & $\begin{array}{l}\text { Clone or host } \\
\text { species }\end{array}$ & Source of the primary antibody & Detection system \\
\hline BVDV & $1: 10,000$ & 15.c. 5 & IDEXX Laboratories & $\begin{array}{l}\text { Envision }+ \text { System-HRP } \\
\text { (Dako, Glostrup, } \\
\text { Denmark) }\end{array}$ \\
\hline BoHV-1 & $1: 40,000$ & $\mathrm{~F} 2$ & VMRD, Pullman, WA, USA & Envision + System-HRP \\
\hline SBV & $1: 3,000$ & rabbit & $\begin{array}{l}\text { (kindly provided by M. Palmarini, } \\
\text { Varela et al., 2013) }\end{array}$ & Envision + System-HRP \\
\hline $\begin{array}{l}\text { Chlamydiaceae } \\
\text { (LPS) }\end{array}$ & $1: 1,000$ & ACI & $\begin{array}{l}\text { Progen GmbH, Heidelberg, } \\
\text { Germany }\end{array}$ & Envision + System-HRP \\
\hline Coxiella burnetii & $1: 20,000$ & rabbit & $\begin{array}{l}\text { Kindly provided by } \mathrm{W} . \\
\text { Baumgärtner }\end{array}$ & Envision + System-HRP \\
\hline Leptospira & $1: 100,000$ & rabbit & NVSL, Ames, IA, USA & Envision + System-HRP \\
\hline $\begin{array}{l}\text { Listeria } \\
\quad \text { monocytogenes }\end{array}$ & $1: 10,000$ & rabbit & $\begin{array}{l}\text { Difco Laboratories, Detroit, MI, } \\
\text { USA }\end{array}$ & Envision + System-HRP \\
\hline Salmonella spp. & 5,000 & mouse, $\mathrm{O}$-antigens & $\begin{array}{l}\text { SIFIN Diagnostic GmbH, Berlin, } \\
\text { Germany }\end{array}$ & Envision + System-HRP \\
\hline $\begin{array}{l}\text { Neospora } \\
\quad \text { caninum }^{\text {a }}\end{array}$ & $1: 20,000$ & goat & VMRD & $\begin{array}{l}\text { Vectastain Elite ABC Kit } \\
\text { (Vector Laboratories) }\end{array}$ \\
\hline $\begin{array}{l}\text { Toxoplasma } \\
\text { gondii }\end{array}$ & $1: 2,000$ & rabbit & Biogenex, Fremont, CA, USA & Envision + System-HRP \\
\hline $\begin{array}{l}\text { Anti-BCG } \\
\text { antibody }^{c}\end{array}$ & $1: 20,000$ & rabbit & Dako, Glostrup, Denmark & Envision + System-HRP \\
\hline
\end{tabular}

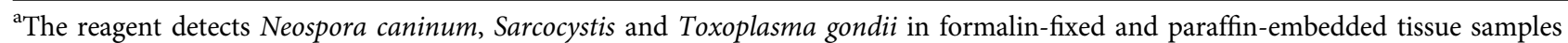

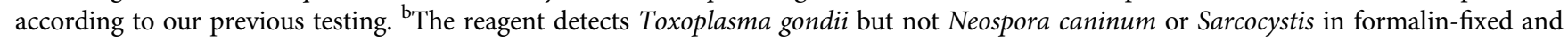
paraffin-embedded tissue samples according to our previous testing. ${ }^{~}$ The reagent detects several bacteria, fungi and parasites (Szeredi et al., 2008). 
Table 2. The number and percentages (\%) of different infectious and non-infectious causes of abortion in cattle, sheep and goat

\begin{tabular}{rcccc}
\hline & Cattle & Sheep & Goat & Total \\
\hline $\begin{array}{r}\text { Known cause } \\
\text { of abortion }\end{array}$ & $95(25)$ & $58(52)$ & $12(32)$ & $165(31)$ \\
Bacteria & $29(7)$ & $37(33)$ & $4(11)$ & $70(13.4)$ \\
Fungi & $4(1)$ & 0 & 0 & $4(1)$ \\
$\begin{array}{r}\text { Protozoa } \\
\text { Viruses }\end{array}$ & $6(2)$ & $1(1)^{\mathrm{a}}$ & 0 & $7(1.3)$ \\
$\begin{array}{c}\text { Suspicious for } \\
\text { infection }\end{array}$ & $41(10)$ & 0 & 0 & $7(1.3)$ \\
$\begin{array}{c}\text { Non-infectious } \\
\text { abortions }\end{array}$ & $8(3)$ & 0 & $1(3)$ & $9(18)$ \\
$\begin{array}{c}\text { The cause of } \\
\text { abortion is } \\
\text { not known }\end{array}$ & $290(75)$ & $54(48)$ & $26(68)$ & $372(69)$ \\
Total & $387(100)$ & $112(100)$ & $38(100)$ & $537(100)$ \\
\hline
\end{tabular}

${ }^{a}$ Inapparent SBV infection is also identified. ${ }^{b}$ Inapparent SBV infection in two cases. ${ }^{~ I n f l a m m a t i o n ~ i s ~ p r e s e n t ~ i n ~ t h e ~ f e t a l ~}$ membranes and/or in fetal organs, but no pathogenic organism could be detected in the affected tissues.

The former category was further divided into six subcategories. (1) Bacterium-induced abortion was diagnosed, when pathogenic bacteria were cultured. Cases showing the growth of opportunistic bacteria in pure or in almost pure culture with the parallel presence of inflammatory infiltration in fetal membranes or organs were also included in this category. Cases with negative bacterial culture result were included in this category as well, when large numbers of bacteria with the same morphology and Gram-staining character in or next to inflammatory infiltrations were observed by histopathological examination. Abortion induced by Chlamydiaceae and C. burnetii was diagnosed, when these agents were detected in the affected tissues using IHC test. Leptospira abortion was the diagnosis if both Warthin-Starry staining and IHC test identified Leptospira in tissue samples. (2) Abortion induced by fungi was the diagnosis if fungal elements were evident in fetal membranes presenting necrotic inflammation. (3) Protozoon-induced abortion was diagnosed when $N$. caninum/Sarcocystis or $T$. gondii were demonstrated using IHC in association with granulomatous inflammation accompanied by focal necroses or haemorrhages and non-suppurative inflammation in brain tissues. (4) The category of virus-induced abortions included abortion cases positive for BVDV, BTV, BoHV-1 or SBV. (5) Cases presenting mild to severe inflammatory infiltration in one or several tissue samples without a detectable pathogen were placed in the category of cases suspicious for infections. (6) Abortion cases of non-infectious origin were put in the last category.

\section{RESULTS}

The results of the study are summarised in Tables 2 and 3. The cause of abortion was determined only in $165(31 \%)$ of
Table 3. Numbers and percentages (\%) of examined abortion cases with identified infectious agents in cattle, sheep and goats

\begin{tabular}{lcclc}
\hline Cause of abortion & Cattle & Sheep & Goat & Total \\
\hline $\begin{array}{l}\text { Bacteria induced } \\
\text { abortion with }\end{array}$ & $11(24)$ & $3(8)$ & 0 & $14(16)$ \\
negative bacterial & & & & \\
culture result & & & & \\
Pathogenic bacteria & $5(10)$ & $33(86)$ & $4(100)$ & $42(47)$ \\
$\quad$ Chlamydiaceae & 0 & $33(86)$ & $4(100)$ & $37(42)$ \\
$\quad$ Coxiella burnetii & $1(2)$ & 0 & 0 & $1(1)$ \\
Listeria monocytogenes & $2(4)$ & 0 & 0 & $2(2)$ \\
$\quad$ Salmonella spp. & $2(4)$ & 0 & 0 & $2(2)$ \\
Opportunistic bacteria & $13(28)$ & $1(3)$ & 0 & $14(16)$ \\
$\quad$ Escherichia coli & $2(4)$ & 0 & 0 & $2(2)$ \\
Streptococcus uberis & $1(2)$ & 0 & 0 & $1(1)$ \\
Trueperella pyogenes & $10(22)$ & 0 & 0 & $10(12)$ \\
$\quad$ Yersinia & 0 & $1(3)$ & 0 & $1(1)$ \\
pseudotuberculosis & & & & \\
Fungi & $4(9)$ & 0 & 0 & $4(5)$ \\
Neospora caninum/ & $6(13)$ & $1(3)^{\mathrm{b}}$ & 0 & $7(8)$ \\
Sarcocystis & & & & \\
BVDV & $4(9)$ & 0 & 0 & $4(5)$ \\
SBV & $3(7)^{\mathrm{c}}$ & 0 & 0 & $3(3)$ \\
Total & $46(100)$ & $38(100)$ & $4(100)$ & $88(100)$ \\
\hline
\end{tabular}

${ }^{\mathrm{a}}$ Bacterial culture of the fetal membranes and/or fetal stomach content remained negative, but groups of bacteria with uniform morphology and of intra- and/or extracellular location could be observed in or next to the area of inflammatory cell infiltration. ${ }^{b}$ Inapparent SBV infection is also identified. 'Inapparent SBV infection in two cases.

the 537 cases. Brucella was not detected. Pathogenic bacteria were identified most often (42 cases), followed by opportunistic bacteria (14 cases), bacterium-induced abortion cases with negative bacterial culture result (14 cases), viruses (7 cases), protozoa (6 cases), fungi (4 cases) and both viruses and protozoa (1 case) among the 88 abortion cases with determined infectious origin (Table 3). Non-infectious cases included malformations ( 4 cases), trauma ( 2 cases), goitre (1 case) and liver fibrosis ( 1 case) in cattle and goitre ( 1 case) in goat abortion cases (Table 2).

Viruses were identified only in the minority of cases $(1.3 \%$, Table 2). Half of those proved to be BVDV infection. Moderate to large numbers of immunolabelled cells were found in the brain in these cases without the presence of any pathological or histopathological changes in fetuses and placenta (Fig. 1B). The remaining four viral abortion cases were positive for SBV by RT-PCR. Malformations were not evident in these cases on pathologic examination. Three cases of SBV infection occurred in calves (two cases in October 2012 and one case in October 2016), and one case in a lamb (in February 2015) in four different farms located in the western and central part of Hungary. SBV was absent in the remaining 533 cases, including 4 cases presenting congenital malformations. SBV was detected using IHC test only in a single calf, which was the first confirmed case of SBV infection in Hungary (Fehér et al., 2017). The presence of a large amount of viral nucleocapsid protein in the axon and cytoplasm of neurons was associated with moderate 


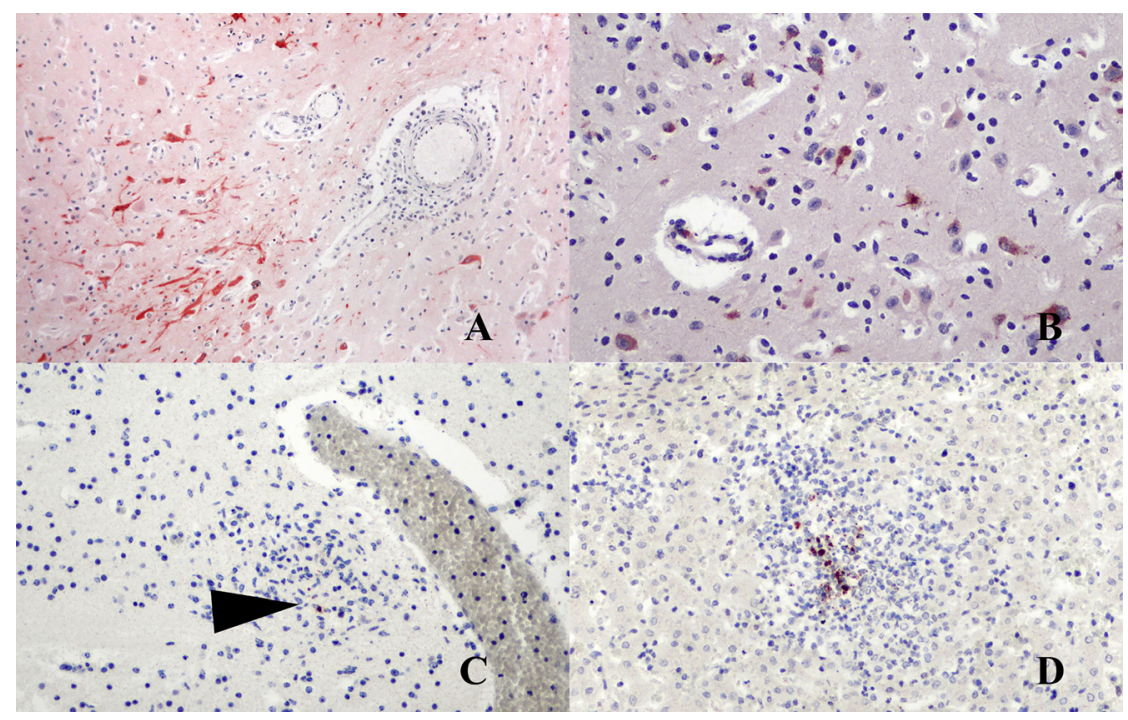

Figure 1. A: Brain, aborted calf. Abortion induced by Schmallenberg virus (SBV). Moderate, non-purulent encephalitis is evident. Large numbers of neurons and axons are immunolabelled with rabbit anti-SBV-nucleoprotein specific reagent. SBV-IHC, $\times 100$. B: Brain, aborted calf. Numerous neurons and an endothelial cell are immunolabelled for BVDV. BVDV-IHC, $\times$ 200. C: Brain, aborted lamb. Focal, granulomatous encephalitis. A single tachyzoite is immunolabelled with anti-Neospora caninum reagent (arrowhead). Parallel presence of inapparent SBV infection was identified using RT-PCR test. Neospora caninum IHC, $\times 200$. D: Liver, aborted lamb. Focal, acute, necropurulent hepatitis with the parallel presence of Chlamydiaceae LPS. Chlamydiaceae IHC, $\times 200$

lympho-histiocytic vasculitis and perivasculitis and the occurrence of several glial nodules in the brain tissue (Fig. 1A). No SBV nucleocapsid protein and no histopathological alterations were found in the fetal lungs, liver, spleen and kidney in this case. Severe dystrophic calcification of the placental connective tissue and acute aspiration of amniotic fluid without inflammatory infiltration in the lungs were observed in the remaining two cases of bovine abortion presenting SBV infection. Tissue lesions were absent from the brain, liver, kidney and spleen in both cases. Histopathological lesions characteristic of protozoal infection were detected in the brain tissue of the SBV-infected lamb, e.g. multifocal granulomatous encephalitis associated with focal necrosis and haemorrhages. Low numbers of tachyzoites were immunolabelled with anti- $N$. caninum reagent (Fig. 1C), while they were not immunolabelled with anti-T. gondii reagent using IHC test. Histopathological lesions were absent from the liver, spleen and kidney of this lamb. Focal dystrophic calcification and multifocal iron deposits suggestive of previous tissue damages were demonstrated in the brain tissue in one of the four calves presenting congenital malformations. Brachygnathia inferior, torticollis and renal agenesis were evident in this calf. Dystrophic calcification or iron deposits were not detected in the brain tissues in any of the SBV-positive cases. BTV and BoHV-1 were not identified in any case.

Chlamydiaceae were the most often detected pathogenic bacteria (Table 3), which were responsible for the majority of abortion cases in small ruminants. Necropurulent placentitis was the main lesion in these cases. Multifocal necropurulent inflammation was evident as well with the parallel presence of Chlamydiaceae antigen in the liver and lungs in a few cases (Fig. 1D). Moderate necropurulent placentitis was found in the case of C. burnetii abortion. Mild to moderate autolysis without any histologic alteration was observed in the abortion cases induced by L. monocytogenes and Salmonella spp. Moderate to large amounts of bacterial antigens could be demonstrated in the fetal organs using IHC in these cases (Fig. 2A and B). Catarrhal to purulent placentitis and/or pneumonia with the parallel occurrence of bacteria were the main histopathological lesions in abortion cases caused by opportunistic bacteria (Fig. 2C). Leptospira spp. were not identified in any case. Fungal hyphae were evident in areas of severe necrotic placentitis in abortion cases induced by fungi (Fig. 2D). In cases of abortion induced by $N$. caninum/Sarcocystis, multifocal glial cell accumulation and the parallel presence of immunolabelled tachyzoites in the brain tissue were the main findings (Fig. 1C). Additionally, lympho-histiocytic vasculitis and scant focal acute haemorrhages were observed in the brain tissue in a few cases as well.

\section{DISCUSSION}

The infectious causes of abortions were similar in the present study to those commonly detected in ruminants in Europe (Borel et al., 2014). The present results are comparable to the findings of a previous report examining sheep and goat abortions in Hungary (Szeredi et al., 2006). However, this is the first study providing data about the different causes of bovine abortion in Hungary. Previously, infectious bovine abortions were detected in $28.5-58 \%$ of the cases 


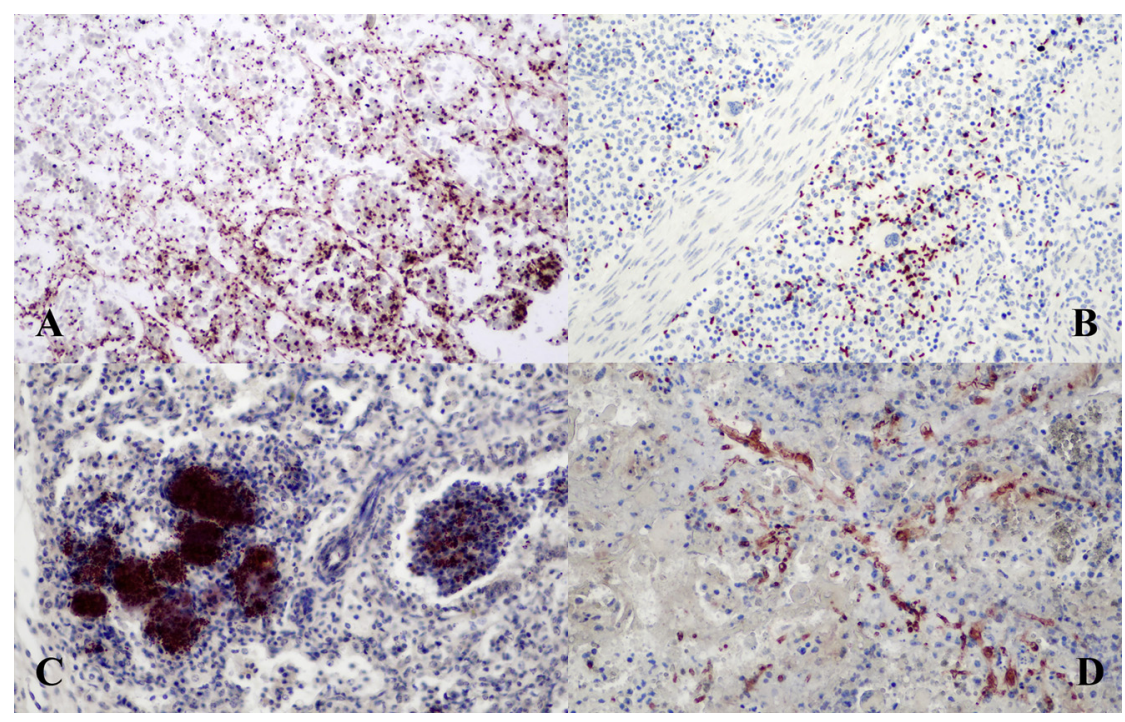

Figure 2. A: Kidney, aborted calf. Large numbers of Listeria monocytogenes bacteria are present in the unaffected tissue. Listeria monocytogenes IHC, $\times 200$. B: Spleen, aborted calf. Large numbers of Salmonella spp. bacteria are present in the unaffected tissue. Salmonella IHC, $\times$ 200. C: Lung, aborted calf. Acute, purulent bronchopneumonia with the parallel presence of numerous bacteria. Trueperella pyogenes was cultured in pure culture from the fetal stomach content. BCG-IHC, $\times 200$. D: Aborted fetal membrane, cattle. Fungus-induced abortion. Necrotic placentitis with the parallel presence of numerous hyphae. BCG-IHC, $\times 200$

(Reitt et al., 2007; Clothier and Anderson, 2016). The frequency of bovine abortions of infectious origin was significantly lower in the present study (16\%) compared to previous studies. Probably the relatively low number of fetal membranes submitted for examination is responsible for this low prevalence $(151 / 537,28 \%)$, since the placenta is the principal target organ for several abortifacient infections. Infectious cause was only suspected in $68(12 \%)$ of the present cases by detecting mild to severe inflammatory infiltration in the fetal organs and placenta (Table 2). In the majority of these cases (61 cases, 90\%) fetal membranes were not sent for examination, which can partly explain the unsuccessful identification of infection.

The re-emergence of SBV epizootics was repeatedly observed in European countries after the first outbreak in 2011 (Wernike et al., 2015; Delooz et al., 2017; Wernike et al., 2018). A similar phenomenon was observed in epizootics caused by Akabane virus, which is closely related to SBV. This might be the result of decreasing herd immunity caused by the appearance of young seronegative animals (Wernike et al., 2018). A comparable re-emergence of an SBV epizootic could be demonstrated in the present study. However, SBV infection was found only sporadically $(4 / 537,0.8 \%)$ in three different years (2012, 2015, and 2016). Only one of these cases could be definitely diagnosed as an SBV-induced abortion, which was the first case of SBV-induced disease in Hungary. Non-suppurative encephalitis was associated with the presence of viral RNA and nucleocapsid protein in the brain tissue in this case, similar to previous reports (Herder et al., 2013; Peperkamp et al., 2015). Fetal neurons were demonstrated to be the primary place of replication of SBV (Herder et al., 2013; Varela et al., 2013), while other fetal tissues had only a minor role in viral growth (Laloy et al., 2017). This was further supported by the result of the present study in which SBV nucleocapsid protein was detected exclusively in fetal brain tissue. Only inapparent viral infection could be determined in the remaining three cases presenting SBV RNA, without the occurrence of SBV nucleocapsid protein and characteristic pathological or histopathological alterations. Protozoal infection was the most likely cause of abortion in one of these cases, while severe dystrophic calcification of the fetal membranes and acute meconium aspiration probably caused by fetal stress were the only findings in the two remaining cases of bovine abortion. The low economic impact of SBV disease in commercial sheep flocks and goat herds was indicated in a previous report as well (Lievaart-Peterson et al., 2015).

$\mathrm{SBV}$ is a teratogenic virus, which can cause varying degrees of deformation in the brain, spinal cord, and extremities (Wernike et al., 2014). A previous report indicates that lambs are much more affected by congenital malformations compared to calves in SBV-infected herds (Dominguez et al., 2014). Only 4 out of 537 (0.8\%) cases presented different types of congenital malformations in this study. No infectious agent could be identified in any of these cases, and all of them were bovine abortion cases. Since SBV might have been eliminated from the infected fetus by the time of abortion, previous SBV infection could not be excluded with complete certainty in these four cases (Bouwstra et al., 2013; De Regge et al., 2013; Herder et al., 2013; Wernike and Beer, 2017). Interestingly, histopathological alterations indicating previous damage of brain tissue (dystrophic calcification and iron deposits) were detected in one of the cases presenting congenital malformations. Corresponding lesions were absent in the fetuses infected with SBV. The low incidence of dystrophic calcification and the presence of iron deposits in the brain tissue was reported previously in SBV-infected malformed fetuses (Herder et al., 2013). 
SBV was identified in $29 \%, 14 \%$ and $9 \%$ of lambs, calves and goat kids, respectively, in the Netherlands by RT-PCR examination of 2,166 malformed newborn animals collected during 6 months at the beginning of the SBV epizootic (Bouwstra et al., 2013). This frequency is significantly higher than that found in the present study. One explanation could be the different type of samples (only malformed fetuses vs. all aborted fetuses). An additional explanation could be the different number of infected arthropod vectors in the two geographical areas. Infected Culicoides biting midges are thought to be the main vectors spreading SBV infection (Wernike and Beer, 2017). We suppose that only a limited number of infected Culicoides reached Hungary, which may have prevented a severe SBV epizootic in this country. Additionally, a recent experimental infection of heifers indicated that bovine fetuses have a natural resistance to SBV infection (König et al., 2019). This could be a further explanation for the extremely low prevalence of SBVinduced abortion, since the majority (72\%) of abortion cases originated from cattle in the present study.

In conclusion, SBV infection played only a minor role in the abortion of domestic ruminants in Hungary in the period of the study. However, suboptimal changes in global climatic conditions in the future, resulting in increasing populations of SBV-infected Culicoides, can dramatically alter this situation.

\section{REFERENCES}

Bilk, S., Schulze, C., Fischer, M., Beer, M., Hlinak, A., and Hoffmann, B. (2012): Organ distribution of Schmallenberg virus RNA in malformed newborns. Vet. Microbiol. 159, 236-238.

Borel, N., Frey, C.F., Gottstein, B., Hilbe, M., Pospischil, A., Franzoso, F.D., and Waldvogel, A. (2014): Laboratory diagnosis of ruminant abortion in Europe. Vet. J. 200, 218-229.

Bouwstra, R. J., Kooi, E.A., de Kluijver, E. P., Verstraten, E. R. A. M., Bongers, J.H., van Maanen, C., Wellenberg, G.J., van der Spek, A. N., and van der Poel, W. H. M. (2013): Schmallenberg virus outbreak in The Netherlands: routine diagnostics and test results. Vet. Microbiol. 165, 102-108.

Clothier, K., and Anderson, M. (2016): Evaluation of bovine abortion cases and tissue suitability for identification of infectious agents in California diagnostic laboratory cases from 2007 to 2012. Theriogenology 85, 933-938.

Delooz, L., Saegerman, C., Quinet, C., Petitjean, T., De Regge, N., and Cay, B. (2017): Resurgence of Schmallenberg virus in Belgium after 3 years of epidemiological silence. Transbound. Emerg. Dis. 64, $1641-1642$.

De Regge, N., van den Berg, T., Georges, L., and Cay, B. (2013): Diagnosis of Schmallenberg virus infection in malformed lambs and calves and first indications for virus clearance in the fetus. Vet. Microbiol. 162, 595-600.

Dominguez, M., Gache, K., Touratier, A., Perrin, J-B., Fediaevsky, A., Collin, E., Bréard, E., Sailleau, C., Viarouge, C., Zanella, G., Zientara, S., and Hendrikx, P. (2014): Spread and impact of the
Schmallenberg virus epidemic in France in 2012-2013. BMC Vet. Res. 10, 248.

Fehér, E., Marton, Sz., Tóth, Á. Gy., Ursu, K., Wernike, K., Beer, M., Dán, Á., and Bányai, K. (2017): Sequence analysis of Schmallenberg virus genomes detected in Hungary. Acta Microbiol. Immunol. Hung. 64, 373-384.

Herder, V., Hansmann, F., Wohlsein, P., Peters, M., Varela, M., Palmarini, M., and Baumgärtner, W. (2013): Immunophenotyping of inflammatory cells associated with Schmallenberg virus infection of the central nervous system of ruminants. PLoS One 8, e62939.

Hofmann, M., Griot, C., Chaignat, V., Perler, L., and Thür, B. (2008): Blauzungenkrankheit erreicht die Schweiz. Schweiz. Arch. Tierheilk. 150, 49-56.

Hoffmann, B., Scheuch, M., Höper, D., Jungblut, R., Holsteg, M., Schirrmeier, H., Eschbaumer, M., Goller, K. V., Wernike, K., Fischer, M., Breithaupt, A., Mettenleiter, T. C., and Beer, M. (2012): Novel Orthobunyavirus in cattle, Europe, 2011. Emerg. Infect. Dis. 18, 469-472.

König, P., Wernike, K., Hechinger, S., Tauscher, K., Breithaupt, A., and Beer, M. (2019): Fetal infection with Schmallenberg virus an experimental pathogenesis study in pregnant cow. Transbound. Emerg. Dis. 66, 454-462.

Laloy, E., Bréard, E., Trapp, S., Pozzi, N., Riou, M., Barc, C., Breton, S., Delaunay, R., Cordonnier, N., Chateau-Joubert, S., Crochet, D., Gouzil, J., Hébert, T., Raimbourg, M., Viarouge, C., Vitour, D., Durand, B., Ponsart, C., and Zientara, S. (2017): Fetopathic effect of experimental Schmallenberg virus infection in pregnant goats. Vet. Microbiol. 211, 141-149.

Lievaart-Peterson, K., Luttikholt, S., Peperkamp, K., Van den Brom, R., and Vellema, R. (2015): Schmallenberg disease in sheep or goats: past, present and future. Vet. Microbiol. 181, 147-153.

Peperkamp, N.H., Luttikholt, S. J., Dijkman, R., Vos, J. H., Junker, K., Greijdanus, S., Roumen, M. P., van Garderen, E., Meertens, N., Van Maanen, C., Lievaart, K., van Wuyckhuise, L., and Wouda, W. (2015): Ovine and bovine congenital abnormalities associated with intrauterine infection with Schmallenberg virus. Vet. Pathol. 52, 1057-1066.

Reitt, K., Hilbe, M., Voegtlin, A., Corboz, L., Haessig, M., and Pospischil, A. (2007): Aetiology of bovine abortion in Switzerland from 1986 to 1995 - A retrospective study with emphasis on detection of Neospora caninum and Toxoplasma gondii by PCR. J. Vet. Med. A 54, 15-22.

Szeredi, L., Jánosi, S., Tenk, M., Tekes, L., Bozsó, M., Deim, Z., and Molnár, T. (2006): Epidemiological and pathological study on the causes of abortion in sheep and goats in Hungary (19982005). Acta Vet. Hung. 54, 503-515.

Szeredi, L., Glávits, R., Tenk, M., and Jánosi, Sz. (2008): Application of anti-BCG antibody for rapid immunohistochemical detection of bacteria, fungi and protozoa in formalin-fixed paraffinembedded tissue samples. Acta Vet. Hung. 56, 89-99.

Varela, M., Schnettler, E., Caporale, M., Murgia, C., Barry, G., McFarlane, M., McGregor, E., Piras, I.M., Shaw, A., Lamm, C., Janowicz, A., Beer, M., Glass, M., Herder, V., Hahn, K., Baumgärtner, W., Kohl, A., and Palmarini, M. (2013): Schmallenberg virus pathogenesis, tropism and interaction with the innate immune system of the host. PLoS Pathog. 9, e1003133. 
Veldhuis, A. M. B., van Schaik, G., Vellema, P., Elbers, A. R. W., Bouwstra, R., van der Heijden, H.M.J.F., and Mars, M.H. (2013): Schmallenberg virus epidemic in The Netherlands: spatiotemporal introduction in 2011 and seroprevalence in ruminants. Prev. Vet. Med. 112, 35-47.

Wernike, K., and Beer, M. (2017): Schmallenberg virus: a novel virus of veterinary importance. Adv. Virus Res. 99, 3960.

Wernike, K., Conraths, F., Zanella, G., Granzow, H., Gache, K., Schirrmeier, H., Valas, S., Staubach, C., Marianneau, P., Kraatz,
F., Höreth-Böntgen, D., Reimann, I., Zientara, S., and Beer, M. (2014): Schmallenberg virus - two years of experiences. Prev. Vet. Med. 116, 423-434.

Wernike, K., Hoffmann, B., Conraths, F. J., and Beer, M. (2015): Schmallenberg virus recurrence, Germany, 2014. Emerg. Infect. Dis. 21, 1202-1204.

Wernike, K., Holsteg, M., Szillat, K.P., and Beer, M. (2018): Development of within-herd immunity and long-term persistence of antibodies against Schmallenberg virus in naturally infected cattle. BMC Vet. Res. 14, 368. 